\title{
Factors Related to The Event of Obesity in The Elderly in Tangerang Selatan \\ ${ }^{1}$ Ade Irma Suryani, ${ }^{2}$ Dewi Putri Syarifah, ${ }^{3}$ Dinda Hasnatul Salsabila, ${ }^{4}$ Dinda Nur Amalia Faculty of Public Health, Muhammadiyah University of Jakarta \\ K.H. Ahmad Dahlan St, Cireundeu, Ciputat, South Jakarta, 15419
}

\begin{abstract}
Obesity has reached epidemic proportions globally, with 2.8 million people dying each year as a result of being overweight or obese. Obesity does not only occur in high-income countries, obesity now also occurs in low- and middle-income countries. Some of the factors that cause obesity include lifestyle, diet, and physical activity. Changes in a more modern lifestyle affect the consumption patterns of individuals who tend to consume more fast food which is generally high in fat and sugar, but low in fiber. In addition, individual physical activity tends to decrease due to technological advances. To determine the factors associated with the incidence of obesity in the elderly in South Tangerang. The research methods is qualitative, with a phenomenological approach, purposive sampling, criteria for adequacy, representativeness, willingness, and clarity of informants to explain the objectives of this study. 4 elderly informants residing in South Tangerang, data analysis by triangulation of sources and triangulation of primary and secondary data observation methods. The sub-categories in this study are physical activity, diet, and lifestyle. From the data above, it can be concluded that obesity does not only occur in adolescents and adults, but also in the elderly. Obesity is excess body weight in conditions of abnormal or excessive fat accumulation in adipose tissue. Obesity in the elderly is a health problem because the prevalence of the elderly in the world is increasing. And the causative factors are the lack of physical activity, lifestyle factors, dietary factors.
\end{abstract}

Keywords: Obesity, Elderly, South Tangerang, Factors 
E-ISSN: 2808-5361

http://e-journal.fkmumj.ac.id/
Proceeding The First

Muhammadiyah Internasional-

Public Health and Medicine

Conference

\section{INTRODUCTION}

Obesitas sudah mencapai proporsi epidemi secara global, dengan sebesar 2,8 juta orang yang telah meninggal setiap tahun akibat dari kelebihan berat badan atau obesitas. Obesitas ini tidak hanya terjadi pada negara-negara berpenghasilan tinggi, obesitas kini juga terjadi di negara-negara berpenghasilan rendah dan menengah. Pemerintah, mitra internasional, masyarakat sipil, organisasi non pemerintah dan sektor swasta semua memiliki peran penting untuk bermain dalam memberikan kontribusi terhadap pencegahan obesitas. Obesitas sudah menjadi masalah yang umum dewasa ini, baik di dunia maupun di Indonesia. Di dunia jumlah penderita obesitas mencapai 1,6 milyar orang. WHO memprediksi di tahun 2015 nanti, jumlah penderita obesitas di dunia akan mencapai 2 sampai 3 miliar orang. Di Indonesia, berdasarkan hasil Riset Kesehatan Dasar (Riskesdas), menunjukkan peningkatan prevalensi obesitas pada penduduk berusia > 18 tahun dari 11,7\% (2010) menjadi 15,4\% (2013). Obesitas tidak hanya berdampak terhadap kesehatan secara fisik, tetapi juga pada masalah sosial dan ekonomi..(Annisa \& Indriasari, n.d.)

Some of the factors that cause obesity include lifestyle, diet, and physical activity. Changes in a more modern lifestyle affect the consumption patterns of individuals who tend to consume more fast food which is generally high in fat and sugar, but low in fiber. In addition, individual physical activity tends to decrease due to technological advances. Ease of access to technology can harm society because nowadays everything can be obtained easily and practically without having to move, for example buying fast food through online transportation service providers. Lack of physical activity with a pattern of consumption of foods high in fat and sugar is the cause of a person experiencing excess nutrition (obesity). (Nugroho et al., 2019)

In the elderly (elderly), physiological functions will decrease due to degenerative processes (aging), so that it can encourage the occurrence of non-communicable diseases. Factors that also affect the health of the elderly are unhealthy eating habits carried out in the past so that at this time it affects their susceptibility to various diseases. The prevalence of central obesity at the national level for the elderly was $18.8 \%$, which was recorded from the age group 55-64 years 23.1\%, 65-74 years $18.9 \%$, and $>75$ years $15.8 \%$. The highest prevalence of obesity occurs in the 55-64 year age group (Nugroho et al., 2019)

Risk factors for obesity include excessive consumption patterns so that the energy produced from food is greater than the energy needed by the body for daily activities, lack of physical activity, socioeconomic factors, psychological factors, heredity factors, and other factors. others such as basal metabolism, endocrine gland disorders, side effects of certain drugs (Dali, 2017)

Creswell in Emzir (2012) states that qualitative research is emphasizing a "complex and holistic" picture, meaning a reference to a complex narrative that invites the reader into the multiple dimensions of a problem or issue and presents it in all its complexity. One of the reasons for choosing 
E-ISSN: 2808-5361

http://e-journal.fkmumj.ac.id/
Proceeding The First

Muhammadiyah Internasional-

Public Health and Medicine

Conference

a qualitative study is because the topic needs to be explored, such as variables that are not easy to identify, theories are not available to explain the behavior of participants or the research population, and theories need to be developed.

Based on the description above, the researchers are interested in knowing the factors associated with obesity in the elderly in South Tangerang.

\section{METHODS}

According to Riskesdas data, in 2014 the prevalence of obesity in the province of Banten in elderly men was $17.8 \%$, while the prevalence of elderly women was $28.6 \%$. Meanwhile, according to the 2014 Ministry of Health data, the prevalence of obesity in the elderly in South Tangerang ranks the second largest at $33.1 \%$ in Banten Province.

This research method is qualitative research with a phenomenological approach with in-depth interviews and document review. This study aims to determine the factors associated with the incidence of obesity in the elderly in South Tangerang. This research was conducted in South Tangerang, Banten, Indonesia in June 2021.

4 informants were interviewed in June 2021, sampling was done online via telecommunications. Sources of information or informants in this study were the closest people, namely the elderly. Informants who will conduct in-depth interviews are 4 elderly people according to the research location. Sampling in this study was selected using a purposive sampling method with the criteria of adequacy, representativeness, willingness, and clarity of informants to explain the objectives of this study.

Data analysis with source triangulation was carried out by conducting in-depth interviews with informants who had been determined according to the criteria. While the triangulation method by reviewing documents from journals by the title and purpose of this study. Observation method with primary data in the form of data collected by in-depth interviews, while secondary data in the form of literature review results by the title and purpose of this study.

Data validity was done by the triangulation method. To maintain the validity of the data, to maintain the validity of the data in this study, source triangulation and method triangulation were used. Source triangulation is done by conducting in-depth interviews with informants who have been determined according to the criteria. While the triangulation method by reviewing documents from journals by the title and purpose of this study. Researchers use this triangulation to ensure the accuracy of the collected informants. The selection of categories and subcategories was discussed together by members of the research team. 


\section{RESULTS AND DISCUSSION}

Table 1. Results of categories and subcategories

\begin{tabular}{|c|c|c|c|c|c|}
\hline $\begin{array}{c}\text { Topic } \\
\end{array}$ & Meaning Unit & Code & Sub Category & Category & $\begin{array}{c}\text { Theme } \\
\end{array}$ \\
\hline Do you often exercise? & $\begin{array}{l}\text { 1. I rarely exercise } \\
\text { because I don't have } \\
\text { much time } \\
\text { 2. Don't exercise } \\
\text { because you have a } \\
\text { busy time } \\
\text { 3. Often exercise by } \\
\text { jogging every } \\
\text { morning } \\
\text { 4. Rarely exercise }\end{array}$ & Exercise frequency & $\begin{array}{l}\text { 1. Rarely exercise } \\
\text { 2. Never exercise } \\
\text { 3. Exercise often Sering } \\
\text { 4. Rarely exercise }\end{array}$ & Physical activity & Factors for obesity \\
\hline $\begin{array}{l}\text { Do you often consume } \\
\text { soft drinks? }\end{array}$ & $\begin{array}{l}\text { 1. Never because I don't } \\
\text { like soft drinks } \\
\text { 2. Never because I don't } \\
\text { like fizzy drinks } \\
\text { 3. Rarely, have you ever } \\
\text { drank a fizzy drink } \\
\text { but it wasn't good } \\
\text { 4. Never because I don't } \\
\text { like fizzy drinks } \\
\text { because it's not good } \\
\text { for health }\end{array}$ & $\begin{array}{l}\text { Frequency of consumption } \\
\text { of soft drinks }\end{array}$ & $\begin{array}{ll}\text { 1. } & \text { Never } \\
\text { 2. } & \text { Never } \\
\text { 3. } & \text { Rarely } \\
\text { 4. } & \text { Never }\end{array}$ & Life style & $\begin{array}{l}\text { Factors for the incidence } \\
\text { of obesity }\end{array}$ \\
\hline $\begin{array}{l}\text { Do you often eat at } \\
\text { night? }\end{array}$ & $\begin{array}{l}\text { 1. Often because you } \\
\text { like to be hungry at } \\
\text { night } \\
\text { 2. Often eat snacks at } \\
\text { night } \\
\text { 3. Often because you } \\
\text { feel hungry } \\
\text { 4. Sometimes it's } \\
\text { because it's better to }\end{array}$ & $\begin{array}{l}\text { frequency of eating at } \\
\text { night }\end{array}$ & $\begin{array}{ll}\text { 1. } & \text { often } \\
\text { 2. } & \text { often } \\
\text { 3. } & \text { often } \\
\text { 4. } & \text { sometimes }\end{array}$ & Lifestyle & Factors for obesity \\
\hline
\end{tabular}




\begin{tabular}{|c|c|c|c|c|c|}
\hline Topic & Meaning Unit & Code & Sub Category & Category & Theme \\
\hline & just sleep & & & & \\
\hline \multirow[t]{6}{*}{$\begin{array}{l}\text { Do you often consume } \\
\text { junk food? }\end{array}$} & $\begin{array}{l}\text { 1. Rarely because I don't } \\
\text { like junk food }\end{array}$ & \multirow[t]{6}{*}{$\begin{array}{l}\text { frequency of consumption } \\
\text { of junk food }\end{array}$} & 1. rarely & \multirow[t]{6}{*}{ Lifestyle } & \multirow[t]{6}{*}{ Factors for obesity } \\
\hline & 2. Rarely because I don't & & 2. rarely & & \\
\hline & $\begin{array}{l}\text { like junk food, I } \\
\text { prefer home cooking }\end{array}$ & & 3. rarely & & \\
\hline & $\begin{array}{l}\text { 3. Rarely, because I } \\
\text { don't like junk food, I }\end{array}$ & & 4. sometimes & & \\
\hline & $\begin{array}{l}\text { prefer homemade } \\
\text { food }\end{array}$ & & & & \\
\hline & $\begin{array}{l}\text { 4. Sometimes only } \\
\text { occasionally } \\
\text { someone brings junk } \\
\text { food }\end{array}$ & & & & \\
\hline \multirow[t]{5}{*}{ Do you often sleep? } & $\begin{array}{l}\text { 1. Yes, because it's easy } \\
\text { to feel weak }\end{array}$ & sleep frequency & 1. often & \multirow[t]{5}{*}{ Lifestyle } & \multirow[t]{5}{*}{ Factors for obesity } \\
\hline & 2. rarely take a nap & & 2. rarely & & \\
\hline & $\begin{array}{l}\text { because of doing } \\
\text { homework }\end{array}$ & & 3. rarely & & \\
\hline & $\begin{array}{l}\text { 3. rarely sleep because } \\
\text { during the day like to } \\
\text { cook food }\end{array}$ & & 4. often & & \\
\hline & $\begin{array}{l}\text { 4. yes what else after } \\
\text { eating }\end{array}$ & & & & \\
\hline
\end{tabular}




\begin{tabular}{|c|c|c|c|c|c|}
\hline Topic & Meaning Unit & Code & Sub Category & Category & Theme \\
\hline $\begin{array}{l}\text { How often do you eat? } \\
\text { Do you like eating too } \\
\text { much? }\end{array}$ & $\begin{array}{l}\text { 1. Twice a day with } \\
\text { sufficient portions } \\
\text { 2. Twice but with fewer } \\
\text { portions because } \\
\text { sometimes lack of } \\
\text { appetite } \\
\text { 3. Often and tend to like } \\
\text { to eat in excess } \\
\text { portions } \\
\text { 4. Often by eating a } \\
\text { little food that } \\
\text { contains prefer } \\
\text { carbohydrates prock or } \\
\text { to eat snacks } \\
\text { snacks }\end{array}$ & $\begin{array}{l}\text { frequency and portion of } \\
\text { meals }\end{array}$ & $\begin{array}{l}\text { 1. Twice a day and } \\
\text { enough } \\
\text { 2. Twice a day and less } \\
\text { 3. Often and excessive } \\
\text { 4. Frequent and } \\
\text { excessive snacks }\end{array}$ & Dietary habit & Factors for obesity \\
\hline $\begin{array}{l}\text { Do you often eat } \\
\text { vegetables and fruit? }\end{array}$ & $\begin{array}{l}\text { 1. Yes, because i like to } \\
\text { eat both } \\
\text { 2. Eat more vegetables } \\
\text { than fruit } \\
\text { 3. Yes every day eat } \\
\text { both } \\
\text { 4. Eat both }\end{array}$ & $\begin{array}{l}\text { frequency of consumption } \\
\text { of vegetables and fruit }\end{array}$ & $\begin{array}{ll}\text { 1. } & \text { Often } \\
\text { 2. } & \text { Eat vegetables often } \\
\text { 3. } & \text { Every day } \\
\text { 4. } & \text { Every day }\end{array}$ & Lifestyle & Factors for obesity \\
\hline
\end{tabular}

Table 2. Code and Category Data Synthesis

\begin{tabular}{|c|c|c|c|c|c|c|c|}
\hline Category & Physical activity & Dietary habit & & & $\begin{array}{l}\text { Lifestyle } \\
\end{array}$ & & \\
\hline Sub-category & $\begin{array}{l}\text { Factors for } \\
\text { obesity }\end{array}$ & $\begin{array}{l}\text { Factors for } \\
\text { obesity }\end{array}$ & $\begin{array}{l}\text { Factors for } \\
\text { obesity }\end{array}$ & Factors for obesity & Factors for obesity & Factors for obesity & Factors for obesity \\
\hline category & 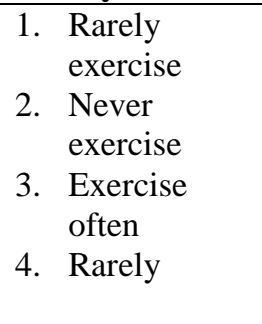 & $\begin{array}{l}\text { 1. Twice a day } \\
\text { and enough } \\
\text { 2. Twice a day } \\
\text { and less } \\
\text { 3. Often and } \\
\text { excessive } \\
\text { 4. Frequent and } \\
\text { excessive }\end{array}$ & $\begin{array}{l}\text { 1. Never } \\
\text { 2. Never } \\
\text { 3. Rarely } \\
\text { 4. Never }\end{array}$ & $\begin{array}{l}\text { 1. Often } \\
\text { 2. Eat vegetables } \\
\text { often } \\
\text { 3. Every day } \\
\text { 4. Every day }\end{array}$ & $\begin{array}{l}\text { 1. Rarely } \\
\text { 2. Rarely } \\
\text { 3. Rarely } \\
\text { 4. Sometimes }\end{array}$ & $\begin{array}{l}\text { 1. Often } \\
\text { 2. Rarely } \\
\text { 3. Rarely } \\
\text { 4. Often }\end{array}$ & $\begin{array}{ll}\text { 1. } & \text { Often } \\
\text { 2. } & \text { Often } \\
\text { 3. } & \text { Often } \\
\text { 4. } & \text { Sometimes }\end{array}$ \\
\hline
\end{tabular}


Volume I Tahun 2021

November 2021
E-ISSN: XXXX-XXXX http://e-journal.fkmumj.ac.id/
Proceeding The First

Muhammadiyah Internasional-

Public Health and Medicine

Conference
(6) 
E-ISSN: 2808-5361

http://e-journal.fkmumj.ac.id/
Proceeding The First Muhammadiyah InternasionalPublic Health and Medicine Conference

\section{Physical Activity}

The following are the results of in-depth interviews with informants related to physical activity, namely exercising informants:

I rarely exercise because I don't have time, the only time I have is taking care of the household...

I don't exercise because I have busy working hours...

I exercise every morning by jogging around the house......

I rarely exercise because my body likes to feel weak......

\section{Lifestyle}

a. Consumption of junk food

The results of in-depth interviews with informants show:

I rarely eat junk food because I don't like it...

I rarely eat it because I don't like junk food, I prefer home cooking

I rarely eat junk food because I don't like junk food, I prefer homemade food

Rarely, only occasionally if someone brings junk food

b. Consumption of Fizzy Drinks

The following are the results of in-depth interviews conducted by researchers:

Never because I don't like to drink fizzy drinks....

Never I don't like fizzy drinks.....

Rarely Have I ever tried to drink coke once......

Never because I don't like fizzy drinks because they are not good for health....

c. Eat at night

The following are the results of in-depth interviews with informants regarding eating at night:

I often eat at night because I like to be hungry at night

I often eat snacks at night

I often because sometimes I like to feel hungry

I sometimes don't like to eat at night because I prefer to sleep

d. Consume fruits and vegetables

The following are the results of in-depth interviews with informants regarding fruit and vegetable consumption:

yes because I like to eat both

I eat more vegetables than fruit

yes every day I eat both

every day I eat both 
e. Sleeping time

The following are the results of in-depth interviews with informants regarding sleep time: yes because sometimes I like to feel weak quickly

I rarely take a nap because I do my homework

I rarely sleep because during the day I like to cook food yes I like to sleep especially after eating

\section{Dietary habit}

a. Meal portion

The following are the results of interviews conducted by researchers to informants:

I eat twice a day with sufficient portions...

I eat twice a day but with fewer portions because sometimes lack appetite...

Often eat and I tend to like to eat too much...

Often eat and I eat a little food that contains carbohydrates I prefer to eat snacks or snacks.

Maintaining ideal body weight should continue to be done early on for both you and your parents. This is to keep the body from becoming obese or underweight. The reason is, a bodyweight that is far from ideal is prone to open various risks of disease, especially for the elderly. Obesity in Elderly research states that obesity can increase the risk of dangerous diseases in the elderly such as hypertension, high cholesterol, diabetes, and heart disease. Meanwhile, being underweight can make the elderly lose muscle mass and are susceptible to disease because their body power decreases.

Physical activity is any activity carried out by the body, namely actions, movements, or activities that trigger and cause an increase in energy expenditure or burning. A person can perform physical activity in the sufficient category with physical exercise or exercise for 30 minutes/day or at least 3-5 days/week (Kemenkes RI, 2011).

Lack of physical activity is probably one of the main causes of the increasing incidence of obesity in affluent societies. People who eat foods rich in fat and do not do a balanced physical activity will experience obesity (Nurcahyo, 2011).

The difference in physical activity in the obese and non-obese elderly, which is not significant, shows that various factors affect physical activity. Problems in the elderly are not only decreased physical activity but also a decrease in diet, organ and psychosocial functions, and weakness. Health workers also need to know that psychosocial and other nutritional problems affect obesity in the elderly.

The age factor will affect physical activity in the group of adults and the elderly, but only obese adults show this change. Meanwhile, weight gain only affects physical activity in adults. 
E-ISSN: 2808-5361

http://e-journal.fkmumj.ac.id/
Proceeding The First

Muhammadiyah Internasional-

Public Health and Medicine

Conference

To stay healthy until old age, from a young age a person needs to get used to a healthy lifestyle. A healthy lifestyle can be done by eating a nutritionally balanced diet, doing physical activity/sports correctly and regularly, and not smoking. This is not as easy as one might think. This healthy lifestyle should have been done since he was young so that when entering old age a person can live his life happily and avoid many health problems. Likewise, the wrong lifestyle can affect health, including drinking less water, lack of movement, eating high-calorie foods, irregular rest habits, and smoking habits (Sediaoetama, 2004, et al).

Physical activity plays a role in energy balance in obese patients. An inactive lifestyle or low activity level is one of the main factors for obesity, in addition to excessive calorie intake (Levine \& Miller, 2007 in Candrawti, 2011).

Obesity is influenced by poor eating habits, especially food consumption that exceeds the limit of needs. Consumption of foods containing sugar, salt, and high fat in the elderly category will increase the risk of hypertension, cholesterol, stroke, coronary heart disease, diabetes mellitus, and gout. Therefore, food intake in the elderly category must be considered by adjusting the diet properly.11 Based on the research that has been done, the most common diseases experienced by respondents are hypertension (30.34\%), gout (17.98\%) ), cholesterol (13.48\%), diabetes, and heart respectively $4.49 \%$.

Based on the results of Riskesdas (2010), the recommended average consumption of fat in Indonesia is 47 grams/day, or $25 \%$ of the total energy consumption. The habit of consuming fatty foods $>7$ times/week has a risk of obesity 1,213 times compared to someone with fatty foods consumption $<7$ times/week. A person who consumes fat/oil more than 67 grams ( 5 tablespoons/day) will increase the risk of hypertension, stroke, diabetes, and heart attack.

\section{CONCLUSION AND SUGGESTIONS}

From the data above, it can be concluded that obesity does not only occur in adolescents and adults, but also the elderly. Obesity is excess body weight in conditions of abnormal or excessive fat accumulation in adipose tissue. Obesity in the elderly is a health problem because the prevalence of the elderly in the world is increasing. And the causative factors are the lack of physical activity, lifestyle factors, dietary factors. As for how to prevent it, namely by exercising regularly and with stages of psychological therapy. We also need to maintain a diet. The need to instill health education in children from an early age, through improving communication, information, and education (KIE), such as the anti-smoking movement, the fiber love movement (vegetables and fruit), a culture of physical activity, and others. childhood obesity such as physical activity (including exercise habits, watching TV, and playing games) as well as variable snacking habits, consumption of junk food, and fast food. 
E-ISSN: 2808-5361

http://e-journal.fkmumj.ac.id/
Proceeding The First Muhammadiyah InternasionalPublic Health and Medicine Conference

Do prevention as early as possible by implementing a healthy lifestyle, doing physical activity well. And if there are symptoms of obesity such as being overweight, you should immediately do a BMI check. If the BMI value is below 18.5, it means that you are underweight or too thin. If the BMI value is 23.0 means you are overweight.

\section{REFERENCES}

1. Turege, J. N., Kinasih, A., \& Kurniasari, M. D. (2019). Hubungan Antara Aktivitas Fisik Dengan Obesitas Di Puskesmas Tegalrejo, Kota Salatiga. Jurnal Ilmu Keperawatan Dan Kebidanan, 10(1), 256. https://doi.org/10.26751/jikk.v10i1.530

2. Nugroho, K. P. A., Triandhini, R. L. N. K. R., \& Haika, S. M. (2019). Identifikasi Kejadian Obesitas Pada Lansia Di Wilayah Kerja Puskesmas Sidorejo Kidul. Media Ilmu Kesehatan, 7(3), 213-222. https://doi.org/10.30989/mik.v7i3.294 
Volume I Tahun 2021

November 2021
E-ISSN: 2808-5361

http://e-journal.fkmumj.ac.id/
Proceeding The First Muhammadiyah InternasionalPublic Health and Medicine Conference 